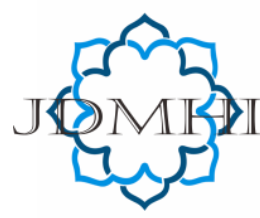

email: jdmhi@walisongo.ac.id

Journal of Digital Marketing and Halal Industry

ISSN: 2716-4810 (print) ISSN: 2716-4802 (online)

\title{
Personal Branding through Da'wah on TikTok Social Media
}

\author{
Amirah Nabilah, Bhunga Aulia, Dwi Yuniar \\ Universitas Al-Azhar Indonesia
}

A R T I C LE I N F O

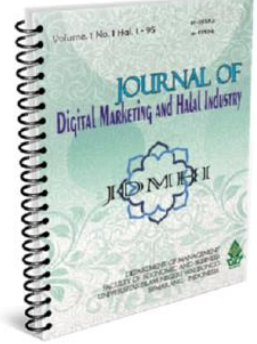

Article history:

Received 7 March 2021

Accepted 22 April 2021

Published 30 April 2021

Keywords:

Personal Branding, Da'wah,

Social Media, TikTok, Husain

Basyaiban.

\begin{abstract}
A B S T R A C T
The COVID-19 pandemic that has hit the world requires people to stay at home, making social media the choice of people to seek entertainment or share knowledge. TikTok is one of the interesting centers for preachers to do their preaching. This study discussed Personal Branding on Husain Basyaiban @basyasman00 account through TikTok social media intending to be achieved by researchers is to find out how personal branding Husain Basyaiban through three da'wah content with the highest viewers on social media TikTok. Husain is a person with successful personal branding through the social media networking platform TikTok, where he presents content about Islamic Da'wah. Based on this, the research team was interested in analyzing how the personal branding process carried out by Husain Basyaiban through Da'wah on the social media platform TikTok. This research uses a qualitative approach with a data collection method in the form of document study, resulting in descriptive data in the form of written words from the behavior studied. The results of the research showed that Husain Basyaiban can meet 11 Criteria for Effective Authentic Personal Branding, namely Authenticity, Integrity, Consistency, Specialization, Authority, Privileges, Relevant, Perseverance, Visibility, Good Deeds, Performance.
\end{abstract}

@2021 Journal of Digital Marketing and Halal Industry

\section{Introduction}

The COVID-19 virus pandemic that has hit all regions of the world has caused a phenomenon that makes all aspects of life change drastically (Dong \& Cao, 2021). Because everyone is required to stay at home so that the virus does not spread, all work and school activities must be carried out at home
(Liu, 2021). In addition to this, people who usually seek entertainment by leaving the house and hanging out with relatives are forced to stay at home, therefore people now tend to seek entertainment through social media, one of which is TikTok (Hew, 2018; Pandela \& Riadi, 2020; Rusli, 2013; Suherdiana \& Muhaemin, 2018; Zulhazmi \& Hastuti, 2018). 
TikTok is a Chinese social network and music video platform. The uploaded video is short, which is a maximum of only 1 minute. The TikTok platform contains various kinds of content uploaded by users or creators, from content about beauty, lifestyle, history, education, art, comedy, to preaching (Pandela \& Riadi, 2020). There is one creator named Husain Basyaiban (@basyasman00), he has followers or followers of $2 \mathrm{M}$ (2 million) with a total of $77.8 \mathrm{M}$ (77.8 million) video likes. Apart from Husain Basyaiban, Ahmad Bafagih (@ahmed_bafagih) has 5,282 thousand followers with a total of 31.4 thousand video likes with 20 posts. And the last one is Syam Aja (@Syam_elmarusy) where he has 1.0M (1 million) followers with a total of 16.7M (16.7 million) video likes with 267 posts. -sama presents da'wah content on the TikTok platform, it's just that researchers chose Husain Basyaiban because he is very unique in delivering and creating Islamic Da'wah content in a way that is easily understood by users or users of the TikTok platform, where users are dominated by Gen Z and Millenials (Islam, 2019; Romadhoni et al., 2020; Rusli, 2013).

Personal branding, in other words, is the process of shaping people's perceptions of the aspects a person has, including personality, abilities, or values, and how they all lead to positive perceptions from society which can ultimately be used as a marketing tool (Rusli, 2013; Thaib, 2019; Wandi, 2020). Based on the background and explanation above, a question arises that will be analyzed by researchers, namely "How is Husain Basyaiban's Branding in the three content with the highest viewers through his preaching on TikTok social media?", So that the researcher aims to find out. how the personal branding carried out by Husain Basyaiban in the three contents with the highest viewers through his preaching on TikTok social media.

\section{Literature Review}

\section{Personal Branding}

According to Timothy P. O'Brien, a personal brand is a personal identity that can create an emotional response to others regarding the qualities and values that a person possesses (Johnson, 2017; Ulfah \& Barry, 2019). Meanwhile, according to Montoya, a personal brand is a strong or clear image that is in the mind of your client (Karaduman, 2013). As befits a product, whether goods or services, so that the brand continues to stick in the hearts of the people it requires an effort that we call branding, which in general, personal branding in other words is a process of forming people's perceptions of the aspects that are owned by. a person, including personality, ability, or values, how all of them can lead to a public perception which in turn can be used as a tool for marketing (Vitelar, 2019). Because the researcher wanted to analyze Husain Basyaiban's Personal Branding process through three da'wah content with the highest viewers on TikTok social media, the personal branding theory used in this study was 11 Criteria for Effective Authentic Personal Branding found by Hubert $\mathrm{K}$. Rampersad (Petruca, 2016). Below are the criteria for personal branding according to Hubert K. Rampersad, namely:

1. Authenticity

Be yourself. An individual is the CEO of his life, therefore the brand must be built from a true personality and must reflect 
the character, behavior, values, and vision of that person.

2. Integrity

A person must adhere to moral and behavioral guidelines that are set by his ambitions or desires.

3. Consistency

It is necessary to have consistency in behavior. To be consistent, it takes courage. Courage to do relevant things over and over again until other people rely on and hold on to us.

4. Specialization

Focus on one area of specialization. Concentrate on one unique talent, talent, or skill. Because being a generalist without any special skills will make someone not special, not unique, and no different.

5. Authority

A person can be valued and viewed by others as an effective leader. Recognized in certain fields where he is recognized as a person who is experienced in his field of doing Personal Branding.

6. Distinctiveness

Distinguish ourselves from others based on our branding. Personal branding needs to be expressed uniquely and differently from competitors and add value to others. Personal branding must be clearly defined so that others can quickly pick up on our branding message.

7. Relevant

A person's branding message must be related to something useful and important to others.

8. Visibility

Messages must be conveyed repeatedly, continuously, consistently so that they can be seen and embedded clearly in the minds of others.

9. Persistence

Personal branding must grow and develop. Therefore it takes a long time, full of dedication, sacrifice, courage, planning, and patience to keep doing it.

10. Goodwill

A person's branding will be known positively by others because of his good deeds and positive values.

11. Performance

Performance is the most important element after a person's branding is known. If we don't act and improve ourselves continuously, personal branding will only become something to be embarrassed about.

\section{Da'wah}

Da'wah itself, according to Nasarudin Latif, states that da'wah is any activity orally or in writing that calls for and invites other human beings to believe and obey Allah Almighty, which is following Islamic beliefs and morals (Andre et al., 2020). Da'wah is also another form of communication where a person conveys messages that are sourced from or following the teachings of the Al-Quran and Sunnah, thus da'wah has a function because it involves activities to encourage people to carry out Islamic teachings, so that all activities in all aspects of life can be colored by Islamic teachings (Hakim, 2021; Ismail et al., 2018). The function of preaching itself is in the form of directing, motivating, guiding, educating, entertaining, reminding mankind to always worship Allah SWT (Rahma \& Mada Wijaya Kusumah, 2020).

\section{TikTok}


TikTok is a social network and music video platform that originated in China (Pandela \& Riadi, 2020). The short video uploaded which has a maximum duration of only 1 minute contains various kinds of content uploaded by users or creators, from content about beauty, lifestyle, history, education, art, comedy, to preaching. Liputan6.com quotes from Tiktok's official statement that in Indonesia the TikTok application is not a new application anymore because in recent years TikTok has begun to be known, only recently popular in 2020. In 2018, TikTok received an award from Google Play as the most entertaining and best application. TikTok is the choice to fill spare time when everyone is faced with this pandemic. Quoted from Sindonews.com, according to Donny Eryastha as the Head of Public Policy for TikTok Indonesia, he said that the $\mathrm{Z}$ gene and the Millennial gene were the most users of TikTok, while in terms of area, Tiktok users in Indonesia came from big cities.

\section{The Method, data, and analysis}

This study used a qualitative approach by producing descriptive data in the form of words in the form of writing from the behavior being studied. A qualitative approach is a complex picture examining words, detailed reports of the respondent's viewpoint, and conducting case studies of natural situations. The paradigm used in this research is the constructivist paradigm. The constructivist paradigm is a paradigm that is almost the antithesis of the understanding that places observation and objectivity in discovering a reality or science. The data collection technique used in this research is document study because it is necessary to analyze content related to research. Document study itself is a qualitative data collection method by viewing or analyzing documents created by the subject himself or others. This is done by researchers to obtain accurate data results according to the source. In addition, the documentation technique will be carried out by watching videos of content from Husain Basyaiban which will then select several videos, this will also take place as long as the researchers conduct research activities. The data analysis technique used a qualitative approach, with descriptive analysis.

\section{Result and Discussion}

The development of Da'wah is quite significant, especially concerning the medium. Da'wah media includes various things, and one of them is by using social media. Social media is currently also developing a lot, and one that is currently popular is Tik Tok media. Tik Tok is an interesting application that is almost used by millions of users. The Tik Tok application provides various facilities, one of which is providing a short video. This short video content has become popular in various circles. The short video content also varies, and one of them is religious or religious content. The owner of the Tik Tok account Husain Basyaiban is an example of having religious content in it. The account has quite high viewers and has various comments in it. Here are some examples of posts containing religious content on Husein Basyaiban's account. 


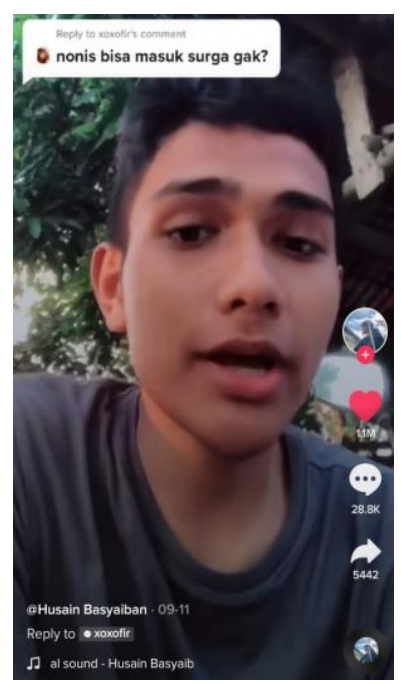

Figure 1. Tiktok Husain Basyaiban account The video received 11 million views, 1.1 million likes, 28.8 thousand comments, and 5,442 shares.

In the video, one of his followers asks whether nonis can go to heaven. Then politely, and apologized in advance, Husain firmly and honestly answered the question.

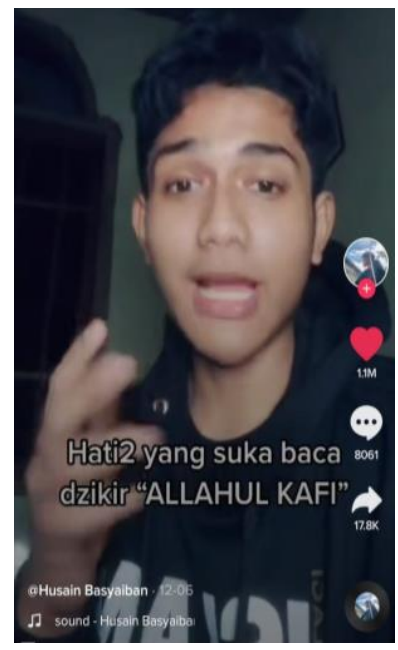

Figure 2. Tiktok Husain Basyaiban account The video received 6.5 million views, 1.1 million likes, 8,061 thousand comments, and 17.8 thousand shares.
In this video, Husain explains the meaning of the recitation of one of the dhikr which if it is done with the wrong way of pronouncing it will change the meaning of the dhikr.

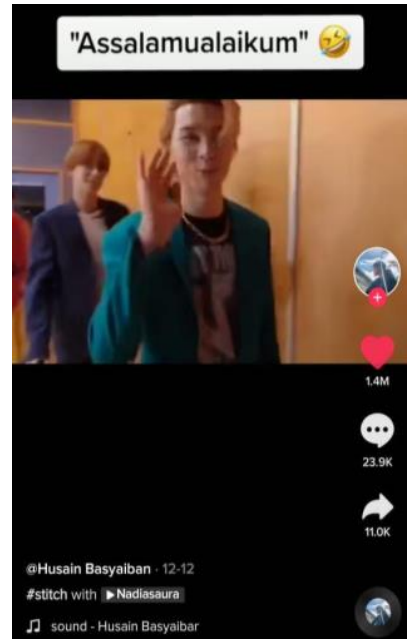

Figure 3. Tiktok Husain Basyaiban account The video received 7.9 million views, 1.4 million likes, 23.9 million comments, and 11 thousand shares.

In this video Husain Basyaiban talks about a K-pop idol who says greetings to his fans with "Assalamu'alaikum" and he discusses how to respond to greetings from a non-Muslim.

Based on the results of research that has been carried out through the method of documentation study by racing by 11 Criteria of Effective Personal Branding, the researcher draws the conclusion that:

1. Authenticity

From the first video, Husain shows his authenticity in a way that he dares to discuss sensitive matters among the community, namely about "non-Muslims can go to heaven". The authenticity of Husain shown in the second video is his quick manner of speaking. Then, 
Husain's authenticity in the last video is one of the preachers who are not offensive to $\mathrm{k}$-poppers. Based on the criteria of authenticity in carrying out personal branding, Husain has his character, namely from the way he speaks quickly and dares to discuss sensitive matters or conversations.

2. Integrity

From the first video, Husain shows his integrity side when answering questions from his followers politely and apologizes first at the beginning of the video so as not to offend his followers, so this proves that Husain is someone who has good morals. From the second video, he has good ethics because he reminds fellow Muslims. From the third video, Husain also has good morals because he can appreciate differences. Based on the integrity criteria in doing personal branding, Husain has moral, ethical, and polite behavior in creating content or answering questions from his followers, so that the content presented does not offend the audience.

\section{Consistency}

In the first video, Husain does his preaching by answering questions from his followers. And in the second video, he delivers da'wah with different material, namely directly providing information to his followers. In the third video, Husain also delivers da'wah by answering questions from his followers, as in the first video. Based on the consistency criteria in conducting personal branding, it can be seen from the three Husain content that he is very consistent in uploading videos and creating content on his account by answering questions from his followers, and the content presented is always about Islamic Da'wah.

4. Specialization

From the first video Husain, in terms of his specialty as a good preacher, is honest and also openly responds to these questions. The second video shows the specialization side as a preacher that Husain brings his message about how to read verses in a language that can be easily understood by young people. From the last video Husain preached, he chose content that should be the current generation of Muslims who like K-pop so they know how to answer greetings from their non-Muslim idols. Based on the specialization criteria in doing personal branding, to meet these criteria, Husain has one area of specialization that he is good at, namely Da'wah.

5. Authority

As seen in the first video, Husain shows the characteristics of his authority when answering the question, he honestly and firmly says that in his belief (Islam), nonMuslims cannot enter heaven. In the second video, Husain also emphatically reminds and also asks his audience not to misread the verse, otherwise, it can change the meaning. Then in the third video, Husain mastered the field of Da'wah and had insight into the Islamic religion, so he could answer correctly (based on the Al-Qur'an) how to reply to greetings from non-Muslims. Based on the criteria for authority in conducting 
personal branding, Husain mastered the field of da'wah, so that he was recognized as an experienced person in preaching on TikTok social media.

\section{Distinctiveness}

In the first video, the specialty that Husain has is when he answers questions openly and shows that without any public being offended. In the second video, Husain can also be said to have a specialty, namely interaction by inviting his followers to be included in the video he made. And in the third video, the specialty that is seen in Husain is when he explains in detail with a super-fast speech. Based on the special criteria for personal branding, Husain has the uniqueness that distinguishes himself from other creators, namely his Da'wah content which is delivered in a way that is easily understood reasonably so that it does not offend.

\section{Relevant}

From the first video, the relevant personal branding characteristic that Husain has is that he knows that TikTok users are not only Muslim, so he answers questions without offending any religion. Then, from the video, the two relevant sides of Husain are when he recites the verse that should be in the Koran. And from the last video, the relevant characteristic that Husain has is that he knows that nowadays $\mathrm{K}$-pop is being liked by many people, so he discusses the content. Based on the relevant criteria in conducting personal branding, where the preaching of Husain discusses issues or problems that are often questioned by the public, but they do not dare to discuss it. Examples are in the object of analysis numbers 1 and 3 .

8. Visibility

In the first video, the visibility that is shown continuously is how she dresses in casual clothes. From the second video, the visibility that Husain shows is how he delivers messages with a speech that is polite, firm, and at a fast tempo. In the third video, the visibility shown is Husain doing the closing in the video funnily or humorously. Based on the visibility criteria in conducting personal branding, it can be concluded that Husain meets these criteria because of the similarities that are displayed continuously from the three videos presented, namely how he dresses and speaks the language.

\section{Persistence}

In the first video, Husain looks very devoted to his preaching so that he can answer questions from his followers very smoothly. In the second video, it can be seen that Husain is very devoted to his knowledge so that there is no change in explaining the meaning of the vowel reading. And in the third video, he can be said to be developing because he follows the trend that is currently booming with many things that are $\mathrm{K}$ Pop. Based on the criteria of persistence in doing personal branding, Husain was successful in being consistent, not giving up, not changing directions, always developing, and focusing on his current field. This is evidenced by the development of his TikTok account which has gained followers of up to 2 million and continues to grow. 
10. Good deeds (Goodwill)

In Husain's first video, the good deeds shown are honest and polite when answering sensitive questions. From the second video, Husain's good deed is to remind his audience to be careful when reading the vowels, because if you pronounce them wrong it can change the meaning. And from the last video, the good deed he does is to remind others of tolerance. Based on the criteria for good deeds in doing personal branding, Husain received a positive response from the public on him, many of his followers gave feedback in the comments column on the three contents above.

\section{Performance}

Based on the first video of the performance, Husain tries his best not to offend anyone with the language and knowledge he knows. From the second video, the performance side that Husain has when he talks about the issue of verses that cannot be mentioned is wrong, because it will change the meaning, he dares to justify it because he has studied it. From the last video, what shows the characteristics of personal branding in terms of performance is that Husain always keeps up with the times (up-to-date) because he carries the K-pop theme which is currently being liked by many young people. Based on the performance criteria in conducting personal branding, Husain performs well through the content presented is also upto-date. This can be seen from the content of object analysis number 3, that it carries the K-pop theme which is currently being liked by many young people.

The application of Personal Branding as a creator through his TikTok account as a whole, Husain Basyaiban meets the criteria of the 11 Criteria of Effective Personal Branding from the book Personal Branding Authentic by Hubert K. Rampersad (Authenticity, Integrity, Consistency, Specialization, Authority, Privileges, Relevance, Persistence, Good Deeds, Performance). The personal branding that he does to convey messages to his followers is by conveying the message of each video in a polite, firm, yet relaxed language so that even ordinary people can understand what is being said. This illustrates the authenticity (authentic) and consistency (consistency) of personal branding. In answering questions related to sensitive matters from his followers on TikTok, he still answers honestly and politely and still tries not to offend others who describe his integrity. Then from the way, he dressed casually but still politely became a differentiator from other preachers who usually always dressed in a turban and robe that described his visibility.

\section{Conclusion}

Based on data analysis and discussion of this research, it can be concluded that the personal branding carried out by Husain Basyaiban in the three contents above is the way he interacts with his followers who ask questions in the comments column and choose topics that will indeed be interesting to discuss and become video content in casual language. and not offensive so that it is easily understood and accepted by the audience. 


\section{Recommendations}

There are deficiencies in this study and it is hoped that further research can carry out a further analysis because the results of our analysis have the potential to be developed into more comprehensive research through in-depth data collection techniques.

\section{References}

Andre, M. ;, Rahmanto, N., \& Satyawan, I. A. (2020). Challenges and Opportunities for Mahasantri Da'wah through Social Media. International Journal of Multicultural and Multireligious Understanding, 7(4), 355-363.

Dong, H., \& Cao, X. (2021). The digital divide behind the news spread of novel coronavirus. Procedia Computer Science, 183 , 820-826. https://doi.org/10.1016/j.procs.2021.0 3.004

Hakim, M. L. (2021). Manajemen Dakwah Pesantren Berbasis Daring: Studi pada Kanal Youtube AlamienTV. Lentera, 4(2), 136-150. https://doi.org/10.21093/lentera.v4i2. 2682

Hew, W. W. (2018). The Art of Da'wah: social media, visual persuasion, and the Islamist propagation of Felix Siauw. Indonesia and the Malay World, 46(134), 61-79.

https://doi.org/10.1080/13639811.201 8.1416757

Islam, M. T. (2019). The Impact of Social Media on Muslim Society: From Islamic Perspective. International Journal of Scientific $\mathcal{E}$ Technology Research, 3(3), 95-
441.

Ismail, A. M., Mujani, W. K., \& Zuhaily, A. A. (2018). Methods of Da'wah and Social Networks in Dealing with Liberalism and Extremism Metode Dakwah dan Jaringan Sosial dalam Menghadapi Liberalisme dan Ekstremisme. Islamiyyat, 40(2), 131-139.

Johnson, K. (2017). The Importance of Personal Branding in Social Media: Educating Students to Create and Manage their Personal Brand. International Journal of Education and Social Science Www.Ijessnet.Com, 4(1), 21-27. www.ripknet.org

Karaduman, İ. (2013). The Effect of Social Media on Personal Branding Efforts of Top Level Executives. Procedia - Social and Behavioral Sciences, 99, 465-473. https://doi.org/10.1016/j.sbspro.2013. 10.515

Liu, P. L. (2021). COVID-19 information on social media and preventive behaviors: Managing the pandemic through personal responsibility. Social Science $\mathcal{E}$ Medicine, 277(April), 113928. https://doi.org/10.1016/j.socscimed.20 21.113928

Pandela, T., \& Riadi, I. (2020). Browser Forensics on Web-based Tiktok Applications. International Journal of Computer Applications, 175(34), 47-52. https://doi.org/10.5120/ijca20209208 97

Petruca, I. (2016). Personal Branding Through Social Media. International Journal of Communication Research, 6(4), 389-392. https://doi.org/10.4018/9781-4666-9593-1.les4 
Rahma, F. N., \& Mada Wijaya Kusumah. (2020). Youtube Sebagai Media Dakwah Masa Pandemi Covid 19 (Studi Analisis Konten Dakwah Channel Muslimah Media Center 15-30 Juni 2020). Dakwah Di Masa Pandemi Covid-19, 19, 41-54.

Romadhoni, L., Anam, D. S., \& Lestari, M. (2020). Smart Uses Da'wah Social Media: Konsep Revolusi Kesehatan Mental Remaja Melalui Strengthening Morals of Islam. Psisula: Prosiding Berkala ..., 2(November), 401-412.

Rusli, N. (2013). Spiritualising New Media: The Use of Social Media for Da ' wah Purposes within Indonesian Muslim Scholars. Jurnal Komunikasi Islam, 03(1), $1-21$.

Suherdiana, D., \& Muhaemin, E. (2018). The Da'wah of Nahdlatul Ulama and Muhammadiyah in Social Media of Facebook. Ilmu Dakwah: Academic Journal, 12(2), 187-200. https://doi.org/10.15575/idajhs.v12i1. 617

Thaib, E. J. (2019). Problems of Da'wah in
Social Media in Gorontalo City Communities. Ilmu Dakwah: Academic Journal for Homiletic Studies, 13(1), 37 53.

https://doi.org/10.15575/idajhs.v12i1. 4412

Ulfah, M., \& Barry, A. (2019). Indonesia Leader Forum, post-truth and political interests in social media and television. International Journal of Communication and Society, 1(1), 17-25. https://doi.org/10.31763/ijcs.v1i1.18

Vitelar, A. (2019). Like Me: Generation Z and the Use of Social Media for Personal Branding. Management Dynamics in the Knowledge Economy, 7(2), 257-268. https://doi.org/10.25019/mdke/7.2.07

Wandi. (2020). Social Media Tik Tok in Islamic Perspective. Alakka:Media and Islamic Communication, 1(1), 13-22.

Zulhazmi, A. Z., \& Hastuti, D. A. S. (2018). Da'wa, Muslim Millennials and Social Media. Lentera, 2(2), 121-138. https://doi.org/10.21093/lentera.v2i2. 1235 